\title{
Assessment of Heavy Metals in Water, Fish and Sediments of the Baleh River, Sarawak, Malaysia
}

\author{
HUI PING CHAI ${ }^{1}$, LEE NYANTI ${ }^{1}$, JONGKAR GRINANG ${ }^{2}$, TECK YEE LING ${ }^{1}$ \\ \& SIONG FONG SIM ${ }^{* 1}$
}

\begin{abstract}
${ }^{1}$ Faculty of Resource Science and Technology, Universiti Malaysia Sarawak, 94300 Kota Samarahan, Sarawak, Malaysia; ${ }^{2}$ Institute of Biodiversity and Environmental Conservation, Universiti Malaysia Sarawak, 94300 Kota Samarahan, Sarawak, Malaysia

*Corresponding author: sfsim@unimas.my
\end{abstract}

\begin{abstract}
This paper reports the heavy metals content in water, sediments and in fish of the Baleh River, in order to evaluate the contamination status of metals. Water and sediment samples were obtained from seven stations located upstream of the Baleh River. Fish species were collected using netting and three species were recorded. Samples were digested and subjected to metal analysis. The findings indicate that there is low risk of metal contamination in water and sediments. Nonetheless some stations were characterized by higher levels of $\mathrm{Fe}, \mathrm{Al}$ and $\mathrm{Mn}$ in water, likely due to accelerated sediment runoff. The acid extractable metal content reported in this study represents the dissolved and weakly-sorbed metals on particulates. For fish, accumulation of heavy metals was found to be more pronounced in the gills, compared to dorsal and ventral muscles. The concentration of $\mathrm{Fe}, \mathrm{Mn}$ and $\mathrm{Al}$ were particularly high in the gills, as these elements were abundant in water. $\mathrm{Hg}$ on the other hand was consistently higher in dorsal and ventral muscles. Generally, concentrations of heavy metals in fishes of the Baleh were well within the permissible limit of Food and Agriculture Organization.
\end{abstract}

Keywords: contamination status, metal analysis, $\mathrm{Fe}, \mathrm{Mn}, \mathrm{Al}$

Copyright: This is an open access article distributed under the terms of the CC-BY-NC-SA (Creative Commons Attribution-NonCommercial-ShareAlike 4.0 International License) which permits unrestricted use, distribution, and reproduction in any medium, for non-commercial purposes, provided the original work of the author(s) is properly cited.

\section{INTRODUCTION}

The popular writer O’Hanlon (1984) describes Baleh as the Heart of Borneo; this part of Sarawak is covered with tropical forest that is home to numerous species of flora and fauna. However, the natural forest has been extensively converted into timber concessions. In 2010, massive debris was carried downstream, causing a major logjam (Sibon, 2010). A subsequent study evidenced that logging activities had affected the water quality of the Baleh River, especially after rainfall events (Ling et al., 2016). Despite the intensive logging activities, the contamination status of the Baleh River, with specific regards to its heavy metal contents is little known. Heavy metals are naturally occurring elements; however, they can also be introduced into the environment via various anthropogenic activities including mining, processing of metals and agriculture (Boudet et al., 2011; Taweel et al., 2011; Raeisi et al.,
2014). When heavy metals are released into the aquatic environment, they are likely to be dissolved in water or bound to particulate matter that eventually settle down and are integrated into the sediment. They can reach a level that is potentially toxic and subsequently, bioaccumulated in different components of the environment, being controlled by various mechanisms (Raeisi et al., 2014). The aim of this study is to report the metals present in water, sediments and in fishes of the Baleh River. The results obtained from this study will serve as baseline data for benchmarking and future monitoring.

\section{MATERIALS AND METHODS}

\section{Study Site}

A total of seven stations were selected from upstream of the Baleh River. The sampling stations are indicated in Figure 1 and the 
corresponding GPS coordinates are summarized in Table 1. A total of three fish species were caught.

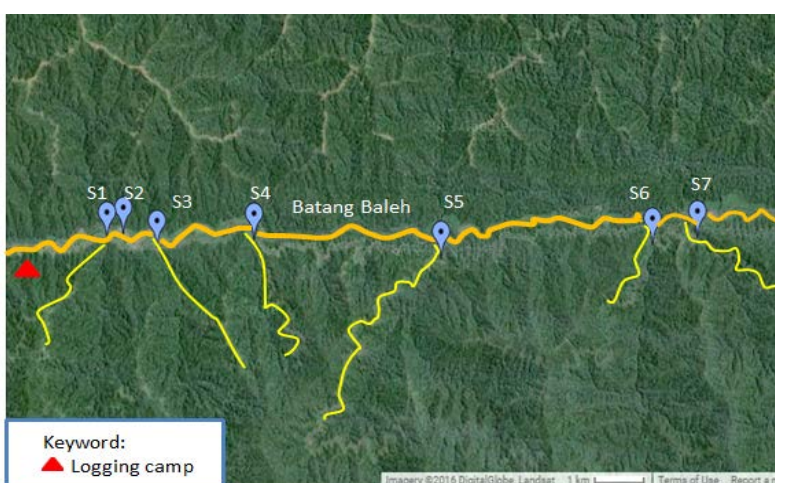

Figure 1. The sampling stations at upstream of the Baleh River, Sarawak.

Table 1. The GPS coordinates of the sampling stations.

\begin{tabular}{|c|c|c|}
\hline Stations & GPS coordinates & Locations \\
\hline S1 & $\begin{array}{l}\text { N0134'05.1" } \\
\text { E114¹5'16.7" }\end{array}$ & Sg. Ukit \\
\hline S2 & $\begin{array}{l}\text { N01³4'07.7" } \\
\text { E114¹5'26.7" }\end{array}$ & Batang Baleh \\
\hline S3 & $\begin{array}{l}\text { N0134'01.1" } \\
\text { E114¹5'47.2" }\end{array}$ & Sg. Kian \\
\hline S4 & $\begin{array}{l}\text { N01³4'04.3" } \\
\text { E114¹6'45.8" }\end{array}$ & Sg. Tor \\
\hline S5 & $\begin{array}{l}\text { N0133'55.2" } \\
\text { E114¹8'38.9" }\end{array}$ & Sg. Irak \\
\hline S6 & $\begin{array}{l}\text { N01³4'02.0" } \\
\text { E114²0'47.2" }\end{array}$ & Sg. Penganen \\
\hline S7 & $\begin{array}{l}\text { N01³4'05.6" } \\
\text { E114²1'14.0" }\end{array}$ & Sg. Selentang \\
\hline
\end{tabular}

\section{Sample Collection}

Water samples were collected in triplicates from subsurface $(0-30 \mathrm{~cm})$ and acidified with $5 \mathrm{~mL}$ of $2 \mathrm{M} \mathrm{HNO}_{3}$. Submerged sediments were obtained using a grab sampler and stored in plastic bags. Fish samples were caught using the netting method and the corresponding total length was recorded (Table 2). The water quality including $\mathrm{pH}, \mathrm{DO}$ and turbidity were also measured in-situ using a multi-parameter water quality sonde (YSI 6920 V2-2). All samples were kept in a cooler box with ice for transportation. Upon arrival at the laboratory, they were transferred to the cold room at $-20^{\circ} \mathrm{C}$ until further analysis.
Table 2. Fish species identified and range of total length.

\begin{tabular}{clc}
\hline No. & Fish species $(\mathrm{n})$ & Length $(\mathrm{cm})$ \\
\hline 1 & Tor tambroides (6) & $10.8-17.5$ \\
2 & Tor douronensis (10) & $15.4-20.2$ \\
3 & Lobocheilos bo (10) & $4.4-8.8$ \\
\hline
\end{tabular}

Tor dourenensis and Tor tambroides are omnivore that are often found in upper stream with clean and fast flowing water containing high dissolved oxygen. Lobocheilos bo is herbivore that is found in shallow, fast flowing river with gravel substrate.

\section{Sample Preparation and Digestion}

Water samples were digested according to the Standard Method of APHA (1998) for its acid extractable metals. The water samples were filtered through $0.45 \mu \mathrm{m}$ membrane filters. A 5 $\mathrm{mL}$ of concentrated $\mathrm{HNO}_{3}$ was added to $100 \mathrm{~mL}$ of water, heated to slow boil on a hotplate until its final volume was approximately $10-20 \mathrm{~mL}$. The sample was left to cool to room temperature, filtered through $0.45 \mu \mathrm{m}$ membrane filters and the filtrate was diluted to $100 \mathrm{~mL}$. For sediment, the samples were air-dried, sieved through a 0.5 $\mathrm{mm}$ sieve, homogenized and ground to fine powder. The samples ( $0.5 \mathrm{~g}$ ) were then digested with $6 \mathrm{~mL}$ concentrated $\mathrm{HNO}_{3}$ and $2 \mathrm{~mL} \mathrm{HCl}$ using the microwave digester (CEM-MARS 6) at $180^{\circ} \mathrm{C}$ and 800 psi. The digested samples were filtered through $0.45 \mu \mathrm{m}$ membrane filters and diluted to $100 \mathrm{~mL}$. Fish samples were washed under tap water to remove dirt and dissected to separate dorsal and ventral muscles, and gills, using a ceramic knife and the samples were oven-dried at $100^{\circ} \mathrm{C}$ for approximately 1 hour. A total $0.25 \mathrm{~g}$ of sample was digested in $6 \mathrm{~mL}$ $\mathrm{HNO}_{3}$ and $1 \mathrm{~mL} \mathrm{HCl}$ using a microwavedigester.

All samples were digested in triplicates and subjected to metal analysis including $\mathrm{Al}, \mathrm{Cu}$, $\mathrm{Mn}, \mathrm{Fe}, \mathrm{Ni}, \mathrm{Zn}, \mathrm{Cr}$, As and Se using Microwave Plasma Atomic Emission Spectrometer (MP AES) (Agilent MP-AES 4200), whilst Hg was analyzed using a mercury analyzer (Perkin Elmer FIMS 400). The metal content reported in water was the acid extractable contents, representing the dissolved and weakly-sorbed metals on particulates. For sediment and fish, the total metal concentrations in dry weight $(\mathrm{dw})$ 
was reported. The metal concentrations in fishes were reported in dry weight for consistency.

All glassware was acid-washed before use and blanks were analyzed for potential contamination. The method was validated using the Certified Reference Materials (CRM) of stream sediment, STSD-1.

The detection limits of MP-AES were evaluated using 21 blank samples: $\mathrm{Al}$ (0.03 ppm); $\mathrm{Cr}$ (0.01 ppm); $\mathrm{Cu}$ (0.01 ppm); $\mathrm{Mn}$ (0.002 ppm); Ni (0.004 ppm); Pb (0.02 ppm); Zn (0.04 ppm); Fe (0.01 ppm); As (0.5 ppm); Se (0.2 ppm). Blank samples were analyzed in every batch of digestion samples to monitor potential contamination.

\section{Determination of Moisture Content}

The permissible guidelines of Food and Agriculture Organization (2012) and Malaysian Food Act (1983) were stipulated in wet weight (ww). The metal concentration in wet weight was estimated from dry weight based on the moisture content determined according to losson-drying method. The weight of fish before and after oven drying at $105^{\circ} \mathrm{C}$ were determined.

$$
\begin{aligned}
& \text { Moisture content (\%) } \\
& \qquad=\frac{W_{\text {before }}-W_{\text {after }}}{W_{\text {before }}} \times 100 \%
\end{aligned}
$$

$$
\begin{aligned}
\text { where } \boldsymbol{W}_{\text {before }} & =\text { weight before drying and } \\
\boldsymbol{W}_{\text {after }} & =\text { weight after drying }
\end{aligned}
$$

\section{Assessment of the Contamination}

The contamination status of sediments was evaluated based on the geo-accumulation index $\left(I_{g e o}\right)$, contamination factor $(C F)$ and pollution load index $(P L I)$. Geo-accumulation index, $I_{\text {geo }}$ (Muller, 1969) was used to illustrate the enrichment of metal concentration above the baseline concentrations as follows: where $C_{\text {sample }}$ is the concentration of elements in samples and $C_{\text {background }}$ is the geochemical background value of world surface rock, as suggested by Martin and Meybeck (1979). The $I_{\text {geo }}$ scale consists of seven grades (0-6) ranging from unpolluted to highly pollute as shown in Table 3.
Table 3. Classification of $I_{g e o}$.

\begin{tabular}{ccl}
\hline$I_{\text {geo }}$ value & Class & Sediment quality \\
\hline$\leq 0$ & 0 & Unpolluted \\
$0-1$ & 1 & Unpolluted to moderately polluted \\
$1-2$ & 2 & Moderately polluted \\
$2-3$ & 3 & Moderately to strong polluted \\
$3-4$ & 4 & Strong polluted \\
$4-5$ & 5 & Strongly to extremely polluted \\
$>6$ & 6 & Extremely polluted \\
\hline
\end{tabular}

The contamination factor (CF) is expressed as where, sediments with $\mathrm{CF}<1$ is classified as low in contamination. Sediments with $1 \leq \mathrm{CF}<3$ is moderately contaminated and $3 \leq \mathrm{CF}<6$ is considerably contaminated (Thomlinson et al., 1980). The pollution load index (PLI) is calculated as $\left(C F_{1} \times C F_{2} \times C F_{3} \times \ldots C F_{n}\right)^{1 / n}$ where $n$ is the number of metals. The PLI value varies from 0 (unpolluted) to 1 (highly polluted).

The hazard risk of $\mathrm{Hg}$ was evaluated based on the Hazard Index (HI), developed by the United States Environmental Protection Agency (US EPA, 1997). The reference dose $\left(\mathrm{R}_{\mathrm{f}} \mathrm{D}\right)$ for total $\mathrm{Hg}$ was $0.0003 \mathrm{mg} / \mathrm{kg}$ body weight per day, whilst the bioavailability factor was assumed 1 to avoid underestimating of the health hazard indices.

$$
\mathrm{HI}=\frac{E D}{R_{f} D}
$$

where $\mathrm{ED}=$ estimated daily dose $(\mathrm{mg} / \mathrm{kg} / \mathrm{BW} /$ day $)$ $\mathrm{R}_{\mathrm{f}} \mathrm{D}=$ reference dose (mg/kg/BW/day)

$$
\mathrm{ED}=\frac{C_{\text {sample }} \times \mathrm{IR} \times \mathrm{BF}}{B W}
$$

$$
\begin{aligned}
& \text { where } \mathrm{C}_{\text {sample }}=\text { concentration in samples }(\mathrm{mg} / \mathrm{kg}) \\
& \qquad \begin{aligned}
\mathrm{IR} & =\text { fish consumption rate }(\mathrm{g} / \mathrm{day}) \\
\mathrm{BF} & =\text { bioavailability factor } \\
\mathrm{BW} & =\text { body weight }(\mathrm{kg})
\end{aligned}
\end{aligned}
$$

The fish consumption rate and body weight are determined according to the guideline recommended by Azmi et al. (2009) for population in Malaysia (adult man 18-59 years old: $66.56 \mathrm{~kg}$; adult woman 18-59 years old: $58.44 \mathrm{~kg}$; fish consumption rate: $0.16 \mathrm{~kg} /$ day). Hazard index (HI) below one indicates no health risk and $\mathrm{HI}$ above 1 and 10 suggests moderate and high hazard risk, respectively. 


\section{Statistical Analyses}

The metal contents were subjected to Principal Components Analysis (PCA) to reveal the clustering pattern of the data, according to sampling locations and fish species. Analysis of Variance (ANOVA) was performed at 95\% significance to determine the significant difference in means of different populations with Tukey's test applied for multiple comparisons.

\section{RESULTS AND DISCUSSION}

\section{Distribution Metals in Water and Sediment}

Heavy metals in water and sediment were examined independently, using PCA to demonstrate the clustering pattern. The scores plots of PC2 vs PC1 are shown in Figure 2. Water samples from S2 located at the main river are observed to occupy the right quadrant of the scores plot and is evidently distinguishable from other stations at the tributaries. This suggests that metal distribution is site-dependent. For sediment, there is no obvious observable grouping.

Table 4 summarizes the average metal concentrations in water and sediments, in comparison to the permissible guidelines of WHO (2006) and Canadian Sediment Quality Guidelines (2001). Typically, higher metal concentrations were found in sediments as these are major repositories that holds more than $99 \%$ of the total metals present in the aquatic environment (Ikem et al., 2003; Ogoyi et al., 2011). The most abundant element detected in water was Fe, with an average of $1.06 \mathrm{mg} / \mathrm{L}$, slightly higher than the permissible level of WHO at $1 \mathrm{mg} / \mathrm{L}$. The permissible guidelines are stipulated based on dissolved metal contents hence was expected lower than the acid extractable content reported in this study. Fe is commonly found in two oxidation states, $\mathrm{Fe}^{2+}$ and $\mathrm{Fe}^{3+}$. In rivers, the median concentration of $\mathrm{Fe}$, usually referred to $\mathrm{Fe}^{2+}$, is $0.7 \mathrm{mg} / \mathrm{L}$ (WHO, 2006). Under reducing environment, the concentration could increase to 0.5 and $1.0 \mathrm{mg} / \mathrm{L}$ as a result of enhanced dissolution of insoluble $\mathrm{Fe}^{3+}$ to soluble $\mathrm{Fe}^{2+}$ (Colter \& Mahler, 2003). Al was the second most abundant element in water, detected at an average of $0.94 \mathrm{mg} / \mathrm{L}$. Generally, the average concentration of $\mathrm{Al}(0.94 \mathrm{mg} / \mathrm{L})$ was higher than the permissible level of WHO at 0.2 $\mathrm{mg} / \mathrm{L}$ whilst $\mathrm{Mn}$ was found with an average above $0.2 \mathrm{mg} / \mathrm{L}$. Other elements such as $\mathrm{Cr}, \mathrm{Cu}$, $\mathrm{Ni}, \mathrm{Pb}, \mathrm{Zn}, \mathrm{Hg}$, As and Se were undetected.

The observed higher concentration of $\mathrm{Al}, \mathrm{Fe}$ and $\mathrm{Mn}$ is likely the result of acidification prior filtration where the metal contents represent the acid extractable concentrations. Essentially, the $\mathrm{pH}$ of water ranged between 7-7.5 with $\mathrm{DO}$ and turbidity fluctuate between 7.79-8.04 mg/L and 15.5-47.08 NTU, respectively. The near neutral $\mathrm{pH}$ suggested that $\mathrm{pH}$ sensitive elements such as $\mathrm{Al}$ are unlikely dissolving naturally whilst these elements are anticipated in oxidation state under the oxygenated environment. The elevated $\mathrm{Fe}$ and Mn concentrations in water was attributed to the same reason of acidication prior filtration. Upon acidification, metals are leached from the suspended solids particularly $\mathrm{Fe}, \mathrm{Mn}$ and $\mathrm{Al}$ which are abundantly found in sediments. This observation is in agreement with the findings of Kim et al. (2004) who stated that acidextractable $\mathrm{Fe}$ and $\mathrm{Mn}$ are significantly higher than the dissolved concentrations. The acid extractable method has become more widespread as an alternative to either of the total or dissolved analysis. According to literatures, the acidextractable analysis removes the biases introduced to samples analyzed for total dissolved metals and provides more accurate prediction on the environment condition. The acid-extractable metals are said to be more representative for environmental considerations as the method of dissolved metals could filter out the precipitated iron oxides which consequently underestimate the Fe content. Besides, the toxic effects of metals may be underestimated as the bioavailable metals from suspended solids are filtered out. The nitric acid added to preserve dissolved metals would cause desorption of metals from clay sediments indicating the available metal concentrations (Kim et al., 2004).

For sediments, metal concentrations of $\mathrm{Cu}, \mathrm{Zn}$ and $\mathrm{Hg}$ were well below the rare effect level, indicative of low risk of pollution, while $\mathrm{Mn}$ and $\mathrm{Pb}$ are well below the threshold effect level. The concentration of $\mathrm{Fe}$ was slightly higher, categorized between probable and occasional effect level while $\mathrm{Cr}$ was categorized between 
(a)

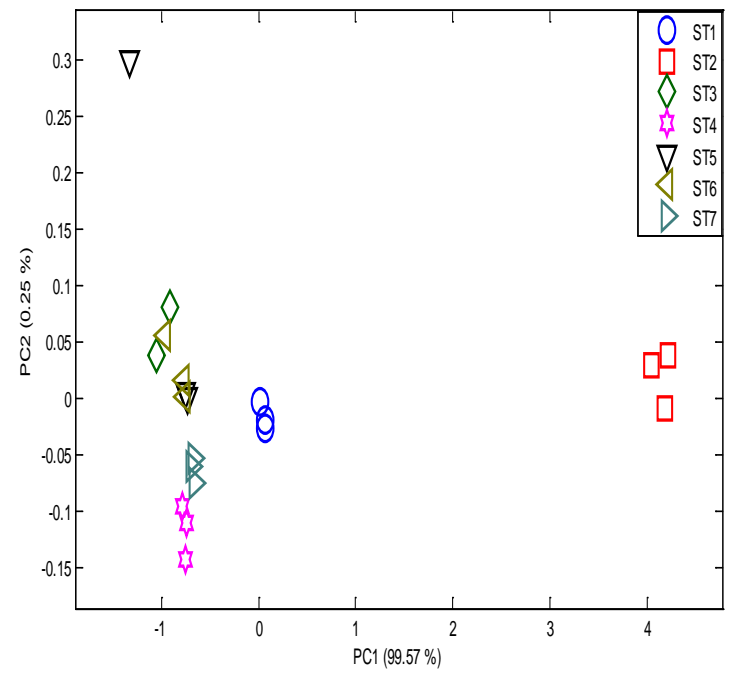

(b)

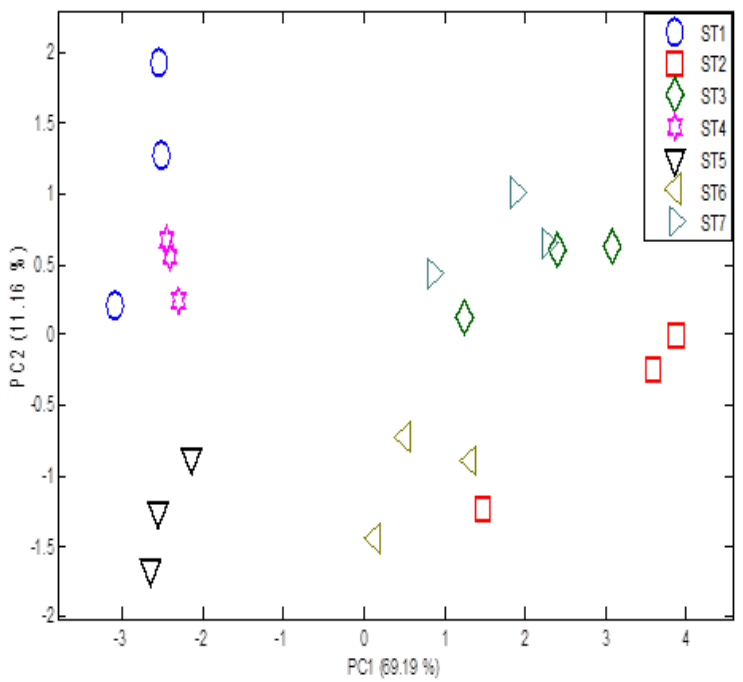

Figure 2. The scores plot of PC2 vs PC1 for heavy metals in (a) water and (b) sediments.

Table 4. The average metal contents in water and sediments in comparison to the permissible guidelines of WHO (2006) and Canadian Sediment Quality Guidelines (2001).

\begin{tabular}{|c|c|c|c|c|c|c|c|c|}
\hline \multirow[t]{2}{*}{ Element } & \multirow{2}{*}{$\begin{array}{l}\text { Water } \\
(\mathrm{mg} / \mathrm{L})\end{array}$} & \multirow{2}{*}{$\begin{array}{l}\text { Sediments } \\
(\mathrm{mg} / \mathrm{kg})\end{array}$} & \multirow{2}{*}{$\begin{array}{c}\text { WHO permissible } \\
\text { level of metals in } \\
\text { drinking water (mg/L) } \\
\text { WHO }\end{array}$} & \multicolumn{5}{|c|}{$\begin{array}{l}\text { Canadian Sediment Quality Guidelines } \\
\text { (2001) (mg/kg) }\end{array}$} \\
\hline & & & & REL & TEL & OEL & PEL & FEL \\
\hline $\mathrm{Al}$ & $0.94 \pm 2.167$ & $51871.26 \pm 3914.275$ & 0.20 & - & - & - & - & - \\
\hline $\mathrm{Cu}$ & nd & $19.88 \pm 5.233$ & 2 & 22 & 36 & 63 & 200 & 700 \\
\hline $\mathrm{Fe}$ & $1.06 \pm 2.077$ & $35495.34 \pm 5733.731$ & 1 & - & 20000 & 30000 & 40000 & - \\
\hline Mn & $0.29 \pm 0.612$ & $446.973 \pm 100.582$ & 0.4 & - & 460 & 780 & 1100 & - \\
\hline $\mathrm{Ni}$ & nd & nd & 0.2 & - & - & 47 & - & - \\
\hline $\mathrm{Zn}$ & nd & $54.975 \pm 6.305$ & 3 & 80 & 120 & 170 & 310 & 770 \\
\hline $\mathrm{Pb}$ & nd & $7.547 \pm 1.234$ & 0.01 & - & 36 & 83 & 130 & - \\
\hline $\mathrm{Cr}$ & nd & $47.479 \pm 5.390$ & 0.05 & - & 43 & 76.5 & 110 & - \\
\hline As & nd & nd & 0.01 & - & 9.8 & 21.4 & 33 & - \\
\hline Se & nd & nd & 0.01 & - & - & - & - & - \\
\hline $\mathrm{Hg}$ & nd & $0.017 \pm 0.008$ & 0.001 & - & 0.18 & 0.64 & 1.1 & - \\
\hline
\end{tabular}

Note: nd: not detected; WHO: World Health Organisation; REL: rare effect level; TEL: threshold effect level; OEL: occasional effect level; PEL: probable effect level; FEL: frequent effect level 
threshold and occasional effect level based on the Derivation of Canadian Sediment Quality Guidelines (2001).

Figure 3 shows the distribution of metals in water and in sediments, according to stations. Apparently, $\mathrm{Fe}$ and $\mathrm{Al}$ are detected at significantly higher concentrations at S2 with an average of $6.00 \mathrm{mg} / \mathrm{L}$ and $6.11 \mathrm{mg} / \mathrm{L}$, respectively. S2 is located at the main river with highly turbid water compared to other stations at the tributaries. The concentrations of $\mathrm{Al}$ and $\mathrm{Fe}$ are positively correlated. They are the most abundant metals in the Earth's crust, demonstrating considerably good correlation above pH 5.5 (Sjöstedt, 2012). Mn also shares similar redox behavior with $\mathrm{Fe}$. Under oxidizing environment, dissolving $\mathrm{Mn}^{2+}$ and $\mathrm{Fe}^{2+}$ were precipitated, yielding insoluble $\mathrm{Mn}^{4+}$ and $\mathrm{Fe}^{3+}$ (Dvorak \& Skipton, 2014). Likewise, Mn was detected at a higher level at S2 (1.74 mg/L) corroborating the trend observed for $\mathrm{Fe}$, indicative that both elements are subjected to similar geochemical process. Elevated $\mathrm{Al}, \mathrm{Fe}$ and $\mathrm{Mn}$ could have associated with the desorption of the elements from suspended particles. For sediment, no significant different was deduced in $\mathrm{Al}, \mathrm{Cr}, \mathrm{Pb}$ and $\mathrm{Hg}$ across stations. Elements including $\mathrm{Fe}, \mathrm{Mn}, \mathrm{Cu}$ and $\mathrm{Zn}$ on the other hand were consistently detected at higher concentrations at S2, S3, S6 and S7 with significant different $(p<0.05)$.

\section{Assessment of Contamination}

The contamination factor (CF) calculated for $\mathrm{Cr}, \mathrm{Al}$, $\mathrm{Cu}, \mathrm{Mn}, \mathrm{Ni}, \mathrm{Zn}$ and $\mathrm{Hg}$ were consistently $<1$, suggesting no risk of contamination. $\mathrm{Fe}$, in the contrary, shows CF value higher than 1 at S2, S3, S6 and $\mathrm{S} 7$ are classified as low in contamination. The geo-accumulation indices, $\mathrm{I}_{\text {geo }}$, and pollution load index (PLI) likewise infer similar conclusion of minimal pollution risk for all elements $\left(\mathrm{I}_{\mathrm{geo}}<0\right.$ and PLI < 1).

\section{Distribution of Metals in Fish}

Heavy metals in fishes were examined using PCA to demonstrate the clustering pattern of samples according to parts. Figure 4 illustrates the scores plot of PC2 versus PC1 with a total of $62.60 \%$ variance explained; the metal distributions in gills were noticeably distinguishable from muscle and belly which occupies the left quadrant.
Table 5 summarizes the metal contents in various species of fish according to dorsal and ventral muscles, and gills. The metal content in muscle was measured due to the significance on human consumption, while the level of metals in gills reflects the concentration of metals in water (Taweel et al., 2011). Most elements were found at higher concentrations i.e. $\mathrm{Cr}(2.42 \mathrm{mg} / \mathrm{kg} \mathrm{dw})$, Fe (594.68 mg/kg dw), Mn (74.70 mg/kg dw), Zn (128.46 mg/kg dw) and $\mathrm{Al}(649.77 \mathrm{mg} / \mathrm{kg} \mathrm{dw})$. Gills are more vulnerable to metal accumulation due to the primarily large surface area that facilitates greater interaction and absorption. The gills exhibited relatively weaker detoxification and therefore the metal burden in gills was high (Taweel et al., 2011). The concentration of Fe, $\mathrm{Mn}$ and $\mathrm{Al}$ were particularly high in gills as these elements were most abundant in water. The metals can penetrate directly through gills when the concentration of metals in water and sediment increases (Jezierska \& Witeska, 2001). According to Ahmad et al. (2015), fishes often demonstrate higher gills ventilation under stress conditions, for example high total suspended solid (TSS) environment. As sediment begins to accumulate in the gill filaments, fishes could excessively open and close their gills and this may consequently accumulate higher metals concentration. Elevated $\mathrm{Al}$ concentration in the aquatic environment may cause clogging of gills (Oughton et al., 1992). Hg, on the other hand, was consistently higher in dorsal and ventral muscles $(0.62-1.42 \mathrm{mg} / \mathrm{kg} \mathrm{dw})$ compared to that in gills $(0.09-0.25 \mathrm{mg} / \mathrm{kg} \mathrm{dw})$ concurring the findings of Łuczyńska et al. (2009). Renieri et al. (2014) revealed that $\mathrm{Hg}$ elimination in muscle was relatively slow and therefore tend to be accumulated over time. The accumulation of $\mathrm{Hg}$ in fish is governed by various abiotic and biotic factors of which feeding habit plays a major role. Carnivorous species at higher trophic level was found to accumulate higher $\mathrm{Hg}$ than herbivorous species that feed on aquatic macrophytes and submerged plants (Ambak \& Zakaria, 2010). In this study, Tor tambroides was found to accumulate relatively higher $\mathrm{Hg}$ than other species.

The metal concentrations in muscle (dorsal and ventral) and gills were examined separately using PCA to demonstrate the clustering pattern according to species. Figure 5 (a, b \& c) illustrates the scores plot according to parts. Noticeably, the distribution of metals in these species is distinguishable. For gills, Lobocheilos bo 
(a)

Elements

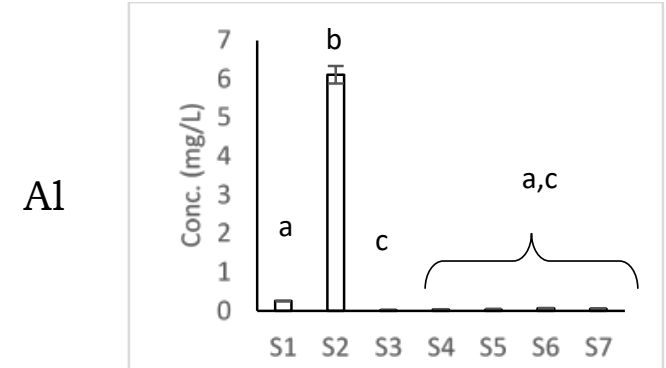

$\mathrm{Fe}$

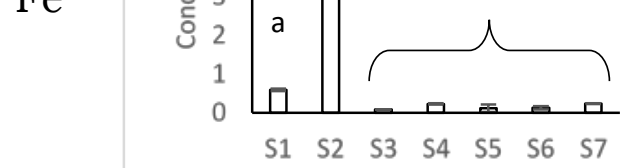

Mn

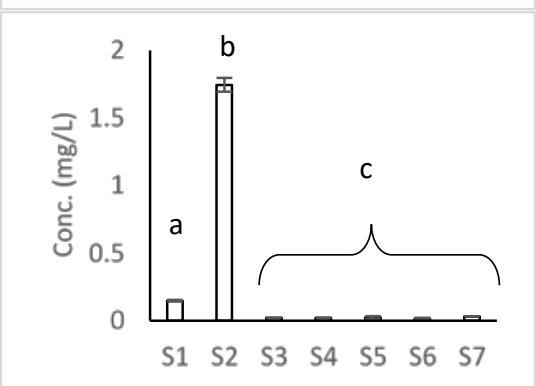

$\mathrm{Cr}$

nd

$\mathrm{Cu}$

nd
Sediment $(\mathrm{mg} / \mathrm{kg})$
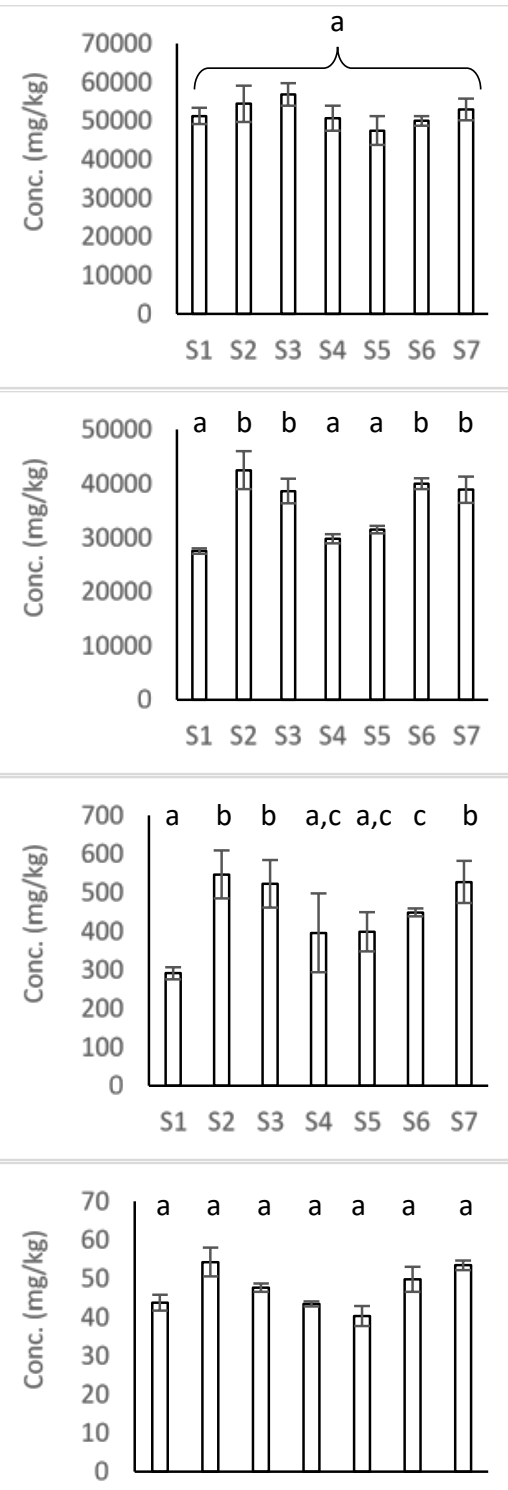

$\begin{array}{lllllll}\text { S1 } & \text { S2 } & \text { S3 } & \text { S4 } & \text { S5 } & \text { S6 } & \text { S7 }\end{array}$

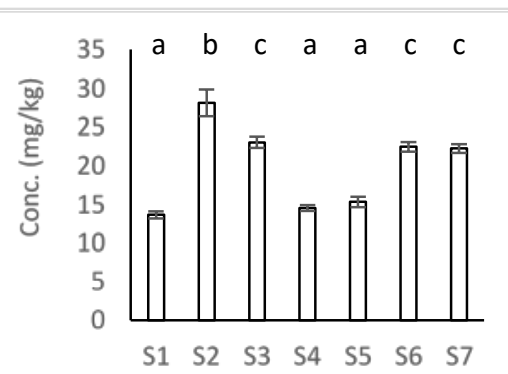




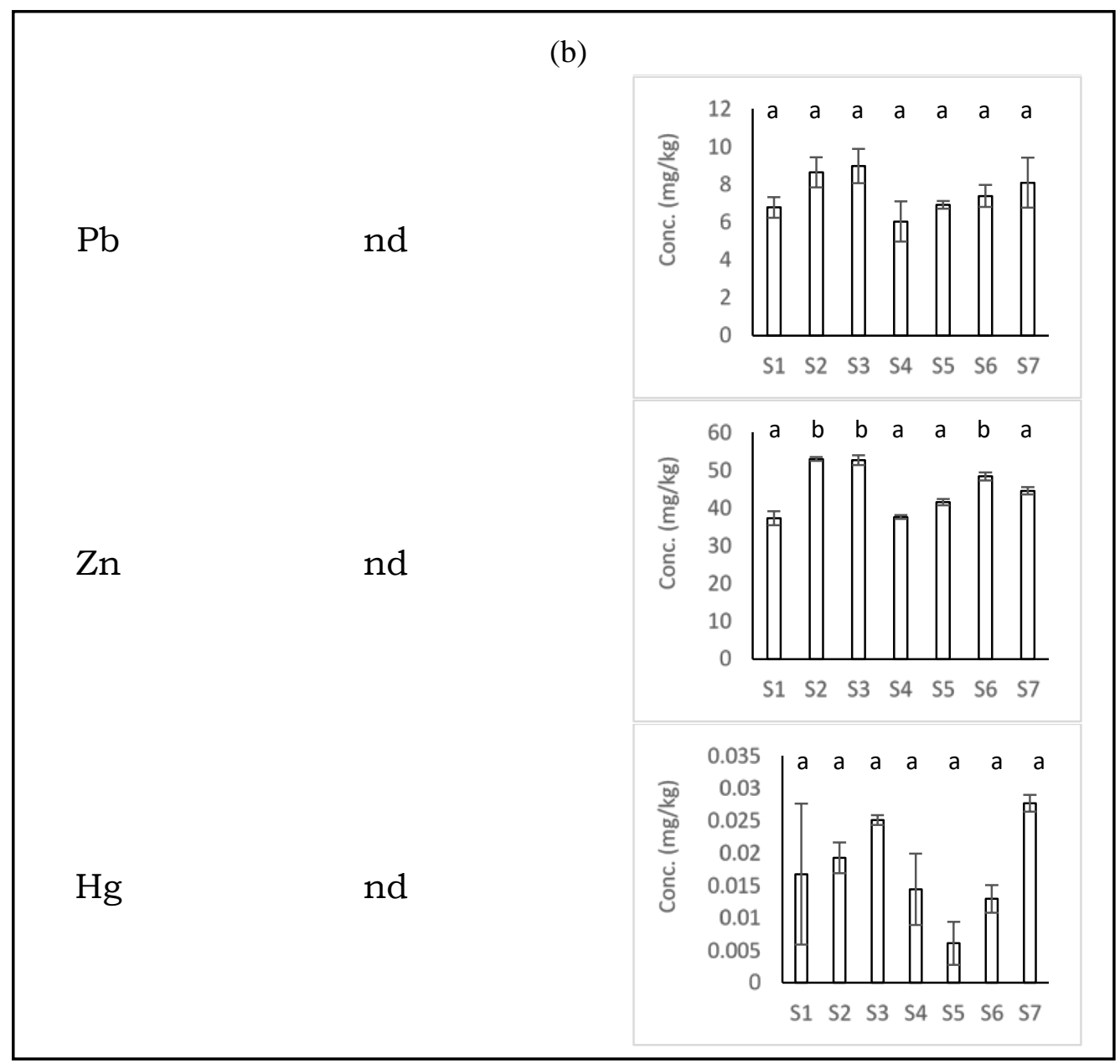

Figure 3. The average metal contents in water and sediment according to sampling stations. (a) $\mathrm{Al}, \mathrm{Fe}, \mathrm{Mn}, \mathrm{Cr}$, $\mathrm{Cu}$; (b) Pb, Zn, Hg. Stations indicated with the same letter suggest no significant. nd - not detected.

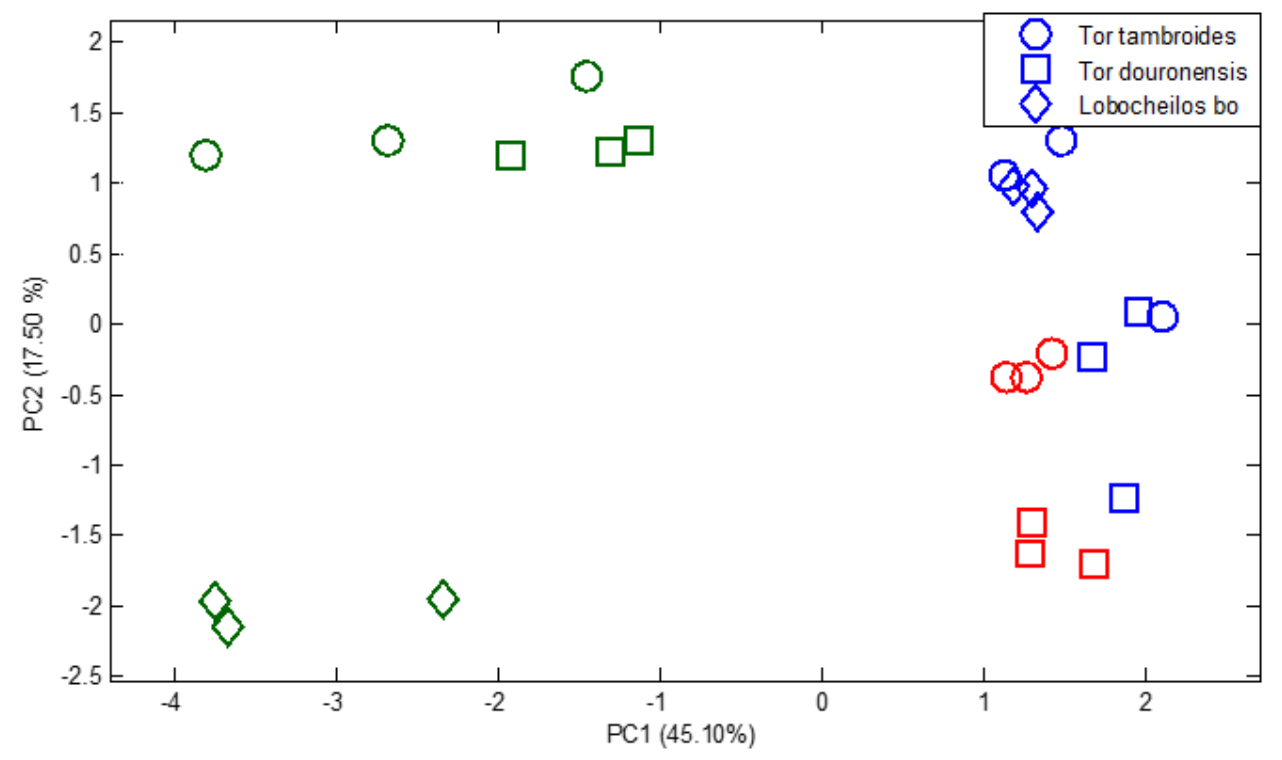

Figure 4. The scores plot of PC2 vs PC1 for heavy metals in fishes. Blue indicates dorsal muscle; red indicates ventral muscle; green indicates gill. 
Table 5. The heavy metals content in three species of fish according to parts. nd - not detected

\begin{tabular}{ccccccccc}
\hline \multirow{2}{*}{$\begin{array}{c}\text { Elements } \\
\text { dry wet } \\
(\mathrm{mg} / \mathrm{kg})\end{array}$} & \multicolumn{3}{c}{ Tor tambroides $(\mathrm{n}=6)$} & \multicolumn{3}{c}{ Tor douronensis $(\mathrm{n}=10)$} & \multicolumn{2}{c}{ Lobocheilos bo $(\mathrm{n}=10)$} \\
\hline $\mathrm{nl}$ & $\mathrm{M})$ & $\begin{array}{c}\text { Ventral } \\
(\mathrm{M})\end{array}$ & Gills & $\begin{array}{c}\text { Dorsal } \\
(\mathrm{M})\end{array}$ & $\begin{array}{c}\text { Ventral } \\
(\mathrm{M})\end{array}$ & Gills & $\begin{array}{c}\text { Dorsal } \\
(\mathrm{M})\end{array}$ & Gills \\
\hline $\mathrm{Al}$ & nd & nd & 569.55 & nd & nd & 316.02 & 59.73 & 1063.74 \\
$\mathrm{Cr}$ & nd & nd & nd & nd & nd & nd & nd & 7.26 \\
$\mathrm{Cu}$ & nd & 2.63 & nd & 0.82 & 2.97 & nd & nd & 2.27 \\
$\mathrm{Fe}$ & 15.76 & 30.1 & 913.77 & 1.39 & 29.62 & 173.78 & nd & 696.49 \\
$\mathrm{Mn}$ & nd & 0.45 & 130.07 & nd & 1.86 & 15.78 & 0.5 & 78.24 \\
$\mathrm{Ni}$ & 0.24 & 0.5 & 0.62 & 0.4 & 0.22 & 0.13 & 1.78 & 0.49 \\
$\mathrm{~Pb}$ & nd & nd & nd & 2.38 & 2.35 & nd & nd & nd \\
$\mathrm{Zn}$ & 58.04 & 67.55 & 169.41 & 40.44 & 40.11 & 154.19 & 25.47 & 61.79 \\
$\mathrm{As}$ & nd & nd & nd & nd & nd & nd & nd & nd \\
$\mathrm{Se}$ & nd & nd & nd & nd & nd & nd & nd & nd \\
$\mathrm{Hg}$ & 1.42 & 1.2 & 0.25 & 0.76 & 0.64 & 0.14 & 0.7 & 0.11 \\
\hline
\end{tabular}

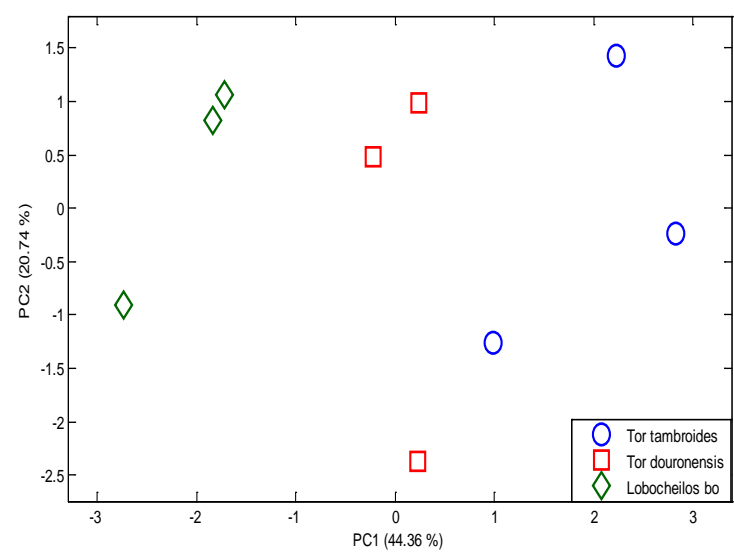

(a) Dorsal muscle

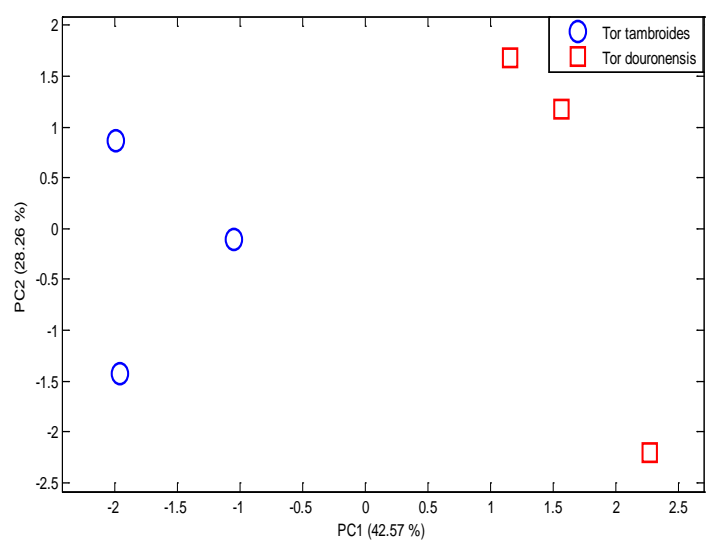

(b) Ventral muscle

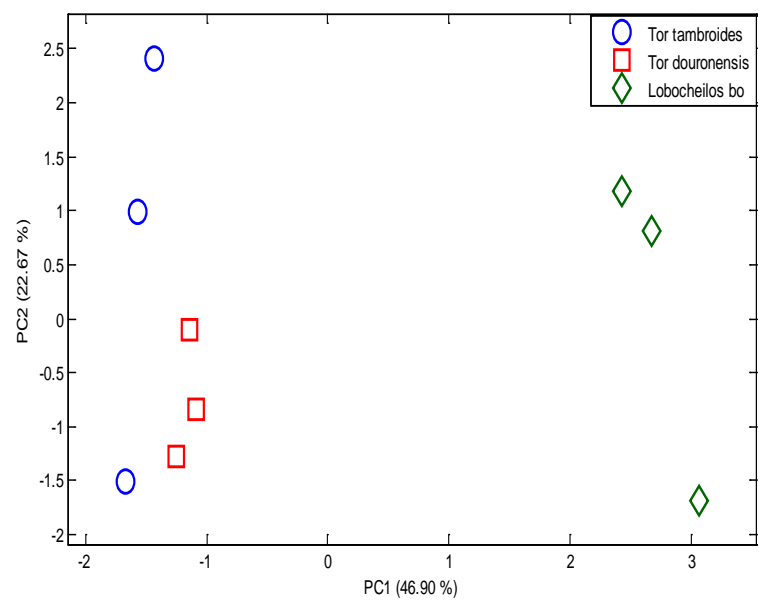

(c) Gills

Figure 5. The scores plot of PC2 vs PC1 for heavy metals in (a) muscle, (b) belly and (c) gills for three different species. 
occupies the right quadrant while Tor tambroides and Tor douronensis occupy the left quadrant. $T$. tambroides and $T$. douronensis are from the same family, this may offer an explanation to the similarity in metal accumulation in gills for both species.

The metals concentration in wet weight is estimated based on the moisture content. The concentrations in wet weight were compared against the guideline of Food and Agriculture Organization (FAO) (2012). All the elements were found comfortably below the permissible level of FAO (Table 6). The hazard index calculated for Hg was likewise consistently less than 1 for all species, indicating no potential health risk.

Table 6. Comparison of the metal content in fish muscle (in wet weight) with the guideline. nd - not detected

\begin{tabular}{lccccc}
\hline $\begin{array}{l}\text { Elements (mg/kg) } \\
\text { FAO Guidelines }\end{array}$ & $\mathrm{Cr}$ & $\mathrm{Cu}$ & $\mathrm{Zn}$ & $\mathrm{As}$ & $\mathrm{Hg}$ \\
$(\mathrm{mg} / \mathrm{kg})$ & $\mathbf{1 . 0}$ & $\mathbf{3 0 . 0}$ & $\mathbf{3 0 . 0}$ & $\mathbf{6 . 0}$ & $\mathbf{0 . 5}$ \\
\hline Tor tambroides & nd & nd & 11.61 & nd & 0.28 \\
Tor douronensis & nd & nd & 8.08 & nd & 0.15 \\
Lobocheilos bo & nd & nd & 5.10 & nd & 0.14 \\
\hline
\end{tabular}

\section{CONCLUSION}

The findings of the study indicate low risk of heavy metal contamination in water, sediments and fishes of the Baleh River. The concentrations of heavy metals detected were well within the permissible guidelines.

\section{ACKNOWLEDGEMENTS}

The authors would like to thank the Sarawak Energy Berhad for funding this project (GL(F07)/SEB/1D/2013(15)).

\section{REFERENCES}

Ahmad, N.I., Noh, M.F., Mahiyuddin, W.R., Jaafar, H., Ishak, I., Azmi, W.N., Veloo, Y. \& Hairi M.H. (2015). Mercury levels of marine fish commonly consumed in Peninsular Malaysia. Environmental Science and Pollution Research, 22(5): 3672-3686.
Ambak, M.A. \& Zakaria, M.Z. (2010). Freshwater fish diversity in Sungai Kelantan. Journal of Sustainability Science and Management, 5(1): 13-20.

APHA 1998. Standard Methods for the Examination of Water and Waste Water. $20^{\text {th }}$ Edition. American Public Health Association; Washington DC.

Azmi, M.Y., Junidah, R., Mariam, S.A., Safiah, M.Y., Fatimah, S., Norimah, A.K., Poh, B.K., Kandiah, M. \& Tahir, A. (2009). Body mass index (BMI) of adults: Findings of the Malaysian Adult Nutrition Survey (MANS). Malaysian Journal of Nutrition, 15(2): 97119.

Boudet L.C., Escalante A, Von Haeften G., Moreno V. \& Gerpe M. (2011). Assessment of heavy metal accumulation in two aquatic macrophytes: a field study. Journal of the Brazilian Society of Ecotoxicology, 6(1): 57-64.

Canadian Environmental Quality Guidelines (2001). Canadian sediment quality guidelines for the protection of aquatic life. Canadian Council of Ministers of the Environment. Retrieved 24 June, 2015 from http://ceqgrcqe.ccme.ca/en/index.html\#void

Colter, A. \& Mahler, R.L. (2003). Iron in drinking water. Environmental Protection, 2: 3-6.

Dvorak, B.I. \& Skipton, S.O. (2014). Drinking Water: Iron and Manganese. Neb Guide, 1714.

Food and Agriculture Organization (2012). Joint FAO/WHO Food Standards Programme. Netherlands: Codex Committee Contaminants in Foods (6th Sessions).

Ikem, A., Egiebor, N.O. \& Nyavor, K. (2003). Trace elements in water, fish and sediment from Tuskegee Lake, Southeastern USA. Water, Air and Soil Pollution, 149(1-4): 5175.

Jezierska, B. \& Witeska, M. (2001). Metal toxicity to fish. University of Podlasie. Monografie No. 42

Kim, B., Steele, K.F. \& Fugitt, T. (2004). Comparison of dissolved and acid-extractable metal concentrations in groundwater, Eastern Arkansas. Journal of the Arkansas Academy of Science, 58: 117-120 
Ling, T.Y., Soo, C.L., Sivalingam, J.R., Nyanti, L., Sim, S.F. \& Grinang, J. (2016). Assessment of the water and sediment quality of tropical forest streams in upper reaches of the Baleh River, Sarawak, Malaysia, subjected to logging activities. Journal of Chemistry, Volume 2016, ID8503931

Łuczyńska, J., Tońska, E. \& Łuczyński, M.J. (2009). Essentials mineral components in the muscles of six freshwater fish from the Mazurian Great Lakes (northeastern Poland). Archives of Polish Fisheries, 17(4): 171-178.

Malaysia Food Act (1983). Food Regulations (Act 281), Fourteenth Schedule (Regulation 38). Maximum permitted proportion of metal contaminant in specific food. Kuala Lumpur, Malaysia: The Commissioner of Law Revision.

Martin, J.M. \& Meybeck, M. (1979). Elemental mass-balance of material carried by major world rivers. Marine Chemistry, 7(3): 173206.

Muller, G. (1969). Index of geo-accumulation in sediments of the Rhine River. Geology Journal, 2(3): 108-118.

O'Hanlon, R. (1984). Into the Heart of Borneo. New York: Vintage Books.

Ogoyi, D.O., Mwita, C.J., Nguu, E.K. \& Shiundu, P.M. (2011). Determination of heavy metal content in water, sediment and microalgae from Lake Victoria, East Africa. The Open Environmental Engineering Journal, 4: 156161.

Oughton, D.H, Salbu, B., Bjørnstad, H.E. \& Day, J.P. (1992). Use of an aluminium-26 tracer to study the deposition of aluminium species on fish gills following mixing of limed and acidic waters. Analyst, 117(3): 619-621.
Raeisi, S., Rad, J.S., Rad, M.S. \& Zakariaei, H. (2014). Analysis of heavy metals content in water, sediments and fish from the Gorgan bay, southeastern Caspian Sea, Iran. International Journal of Advanced Biological and Biomedical Research, 2(6): 2162-2172.

Renieri, E., Alegakis, A., Kiriakakis, M., Vinceti, M., Ozcagli, E., Wilks, M. \& Tsatsakis, A. (2014). Cd, $\mathrm{Pb}$ and $\mathrm{Hg}$ biomonitoring in fish of the Mediterranean region and risk estimations on fish consumption. Toxics, 2(3): 417-442.

Sibon, P. (2010). Logjam a man-made disaster. Borneo Post Online. Retrieved from http://www.theborneopost.com/2010/10/14/' logjam-a-man-mad-disaster'/

Sjöstedt, C. (2012). Iron and aluminum speciations in Swedish freshwaters. KTH Land and Water Resources Engineering, ISSN 1650-8602.

Taweel, A., Shuhaimi-Othman, M. \& Ahmad, A.K. (2011). Heavy metals concentration in different organs of tilapia fish (Oreochromis niloticus) from selected areas of Bangi, Selangor, Malaysia. African Journal of Biotechnology, 10(55): 11562-11566.

Thomlinson, D.L., Wilson, J.G., Harris, C.R. \& Jeffney, D.W. (1980). Problems in the assessment of heavy metal levels in estuaries and the formation of a pollution index. Helgoländer Wissenschaftliche Meeresuntersuchungen, 33(1): 566-572.

USEPA (United States Environmental Protection Agency) (1997). Exposure Factors Handbook (1997 Final Report).Washington, DC: U.S. Environmental Protection Agency. Retrieved 6th December 2016.

WHO 2006. Guidelines for Drinking Water Quality. Third Edition. WHO Press, World Health Organization; Geneva. 